\title{
Meconium Aspiration Syndrome
}

National Cancer Institute

\section{Source}

National Cancer Institute. Meconium Aspiration Syndrome. NCI Thesaurus. Code C87093.

A serious condition in which a newborn breathes a mixture of meconium (the first intestinal discharge) and amniotic fluid into the lungs around the time of delivery. Meconium aspiration syndrome occurs in 5-10 percent of births and typically occurs when the infant is stressed, as when the infant is past its due date. 